\title{
New Sources of Resistance to Phytophthora sojae in the Soybean Plant Introductions
}

\author{
A. E. Dorrance and A. F. Schmitthenner, Department of Plant Pathology, The Ohio State University, Wooster \\ 44691-4096
}

\begin{abstract}
Dorrance, A. E., and Schmitthenner, A. F. 2000. New sources of resistance to Phytophthora sojae in the soybean plant introductions. Plant Dis. 84:1303-1308.

Single dominant Rps genes have been highly effective in managing Phytophthora sojae. However, numerous physiological races of $P$. sojae have developed in response to deploying single gene resistance. New sources of resistance with potentially novel Rps genes are needed. A selection of accessions (PI273483 to PI427107) from the United States Department of Agriculture Soybean Germplasm collection were evaluated for resistance to P. sojae using the hypocotyl inoculation technique for $R p s$ genes and the layer test for partial resistance. Of the 1,015 accessions tested, 159 accessions were susceptible to races 7 (vir $1 a, 2,3 a, 3 c, 4,5,6,7), 17$ (1b, $1 d$, $2,3 a, 3 b, 3 c, 4,5,6,7)$, and $25(1 a, 1 b, 1 c, 1 k, 7)$. However, 162 accessions were resistant to these three races and 32 accessions were resistant to an additional five races chosen specifically to elicit a susceptible interaction with two and three Rps gene combinations. In addition, 55.5\% of the 887 accessions tested had high levels of partial resistance or tolerance (scores $\leq 4.0$ ) to $P$. sojae. The majority of the accessions that were resistant to all of the races tested and those that had very high levels of partial resistance originated in the Republic of Korea. These results indicate that this region is an area with many sources of resistance to $P$. sojae for both specific Rps genes and partial resistance.
\end{abstract}

Additional keywords: partial resistance, Phytophthora root rot, Phytophthora stem rot

Phytophthora sojae is the major pathogen of soybeans in Ohio and contributes to losses in several production regions in the United States and the world $(13,26)$. Under saturated soil conditions, $P$. sojae produces motile zoospores which locate and infect soybean plants throughout the growing season. Phytophthora seed rot and damping off are early-season diseases, whereas Phytophthora stem rot occurs at mid- to late season.

Host resistance has been an effective tactic for managing Phytophthora damping off and stem rot (16). Single Rps genes which interact with $P$. sojae in a gene-forgene system (6) have been utilized extensively. In contrast, partial resistance (formerly described as tolerance [25], general resistance, and rate reducing resistance [20]) has been used to a limited extent. Soybeans with partial resistance to $P$. sojae develop root rot following infections but

Corresponding author: A. E. Dorrance

E-mail: dorrance.1@osu.edu

Salaries and research support provided by State and Federal Funds appropriated to the Ohio Agricultural Research and Development Center, the Ohio State University. Funding for this research was provided in part by the Ohio Soybean Council.

Accepted for publication 28 August 2000.

Publication no. D-2000-1011-01R

(c) 2000 The American Phytopathological Society damage is limited in comparison with susceptible cultivars.

Single resistance genes have provided a somewhat durable disease management strategy. Cultivars with single Rps genes were first deployed in Ohio during the 1960s. Thirteen Rps genes have been identified, of which eight (Rpsla, Rpslb, Rps1c, Rps1k, Rps2, Rps3a, Rps6, and Rps7) have been used in commercial soybean cultivars. Following deployment of each single Rps gene, races of $P$. sojae were subsequently identified that had a susceptible interaction with the Rps gene. Single Rps genes have been effective for 8 to 15 years, depending on inoculum density and environmental conditions (16). Phytophthora root rot was identified in fields in which cultivars with the single gene Rpslk were grown as early as 1990 in Ohio (18). Races of $P$. sojae that elicit a susceptible interaction with Rpslk have also been isolated from soil in Indiana (1) and plants in Iowa (28) during 1993 and 1991 , respectively. In addition, races of $P$. sojae with virulence pathotypes for Rps genes that have never been deployed have also been identified $(1,18,21)$.

As the complexity of the virulence pathotypes of $P$. sojae continues to increase and the number of designated races increases in soybean production fields, finding additional sources of partial resistance and incorporation of this resistance into commercial cultivars will be essential to manage this disease effectively. There is evidence that partial resistance is a highly heritable, quantitative trait $(4,25)$. St. Martin et al. (19) reported that partial resistance (tolerance) does not negatively impact yield potential of soybean cultivars. In addition, differences in yield among cultivars planted in $P$. sojae-infested soil could be attributed to the degree of partial (ratereducing) resistance present in the cultivar (22).

Plant breeders favor single gene resistance due to ease of incorporation. Therefore, new sources of resistance need to be identified in order to maintain single Rps genes as a viable tool. Various strategies have been used to screen soybeans for possible new Rps genes and gene combinations. Lohnes et al. (11) inoculated soybean plant introductions (PIs) from eastern China with four different isolates which represented $P$. sojae races $1,7,17$, and 25 . These races had corresponding virulence pathotypes for all of the 13 identified single Rps genes and many gene combinations. Kyle et al. (9) screened a collection of soybean PIs with 10 different races of $P$. sojae, many of which had very similar virulence pathotypes.

In order to identify new sources of resistance and subsequently novel Rps genes, we used a strategy in which three isolates were chosen which had virulence pathotypes encompassing each of the Rps genes and many combinations similar to Lohnes et al. (11) for the preliminary screening. For those accessions which were resistant to these three isolates of $P$. sojae, additional isolates were then selected with virulence pathotypes for specific two- and three-gene combinations which, if present, would have a susceptible interaction. The purpose of this study was to identify new sources of Rps and partial resistance to $P$. sojae in the United States Department of Agriculture (USDA) Soybean Germplasm collection.

\section{MATERIALS AND METHODS}

Plant introductions. The soybean germ plasm examined in this study included PI accession numbers PI273483 to PI 427107 , in maturity groups 000 to IV, from the USDA Soybean Germplasm Collection in Urbana, IL. Laviolette and Athow previously evaluated many of the accessions in this collection for resistance to frogeye leafspot race 2 and $P$. sojae races $1,2,3$, and 4 (12). Some lines also were evaluated for reaction to $P$. sojae races $5,6,7,8$, and 
9 (12). The 1,015 accessions selected for the current study were resistant or not tested in Laviolette and Athow's previous evaluation. In the sample, 69 and $22 \%$ of the accessions originated in South Korea and Japan, respectively; whereas only 7\% of the accessions originated in China. In addition, one to four accessions originated from each of the following countries: France, Germany, Hungary, Poland, Romania, Russia, Sweden, Taiwan, and Yugoslavia.

Detection of sources of $\boldsymbol{R p s}$ genes. The isolates that were used in inoculations and their virulence pathotype are listed in Table 1. All of the isolates originated in Ohio. Races 7, 17, and 25 collectively have susceptible interactions with all of the designated Rps genes and many Rps gene combinations. Additional isolates were then selected which elicit a susceptible interaction with specific 2-Rps gene combinations (Table 2). For example, $P$. sojae race 31 has a susceptible interaction with an Rps gene combination of Rps $1 k$ and Rps6, but races 7,17 , or 25 have a resistant reaction. The race designations for $P$. sojae are based on the susceptible reaction of 8 of the 13 differentials Rpsla, Rps1b, Rps1c, Rpsld, Rpslk, Rps3a, Rps6, and Rps7 $(1,18,28)$. We used the combination of race-isolate code for $30-\mathrm{T}$ to indicate that there is a difference in the pathotype among two isolates which are designated $P$. sojae race 30 (Table 1 ).

The hypocotyl inoculation technique (17) was used to evaluate the accessions for Rps genes. Inoculum was prepared by growing $P$. sojae for approximately 7 days on lima bean soft agar (12 $\mathrm{g}$ of agar per

Table 1. Differential reaction and race designations of isolates of Phytophthora sojae used to detect new sources or resistance in soybean plant introductions (PI 273483-427107)

\begin{tabular}{ll}
\hline Race $^{\mathrm{a}}$ & \multicolumn{1}{c}{ Virulence pathotype $^{\mathrm{b}}$} \\
\hline 7 & $1 \mathrm{a}, 2,3 \mathrm{a}, 3 \mathrm{c}, 4,5,6,7$ \\
17 & $1 \mathrm{~b}, 1 \mathrm{~d}, 2,3 \mathrm{a}, 3 \mathrm{~b}, 3 \mathrm{c}, 4,5,6,7$ \\
25 & $1 \mathrm{a}, 1 \mathrm{~b}, 1 \mathrm{c}, 1 \mathrm{k}, 7$ \\
31 & $1 \mathrm{~b}, 1 \mathrm{c}, 1 \mathrm{k}, 2,3 \mathrm{c}, 4,5,6,7$ \\
$30-\mathrm{T}$ & $1 \mathrm{a}, 1 \mathrm{~b}, 1 \mathrm{k}, 2,3 \mathrm{a}, 3 \mathrm{c}, 4,5,6,7$ \\
30 & $1 \mathrm{a}, 1 \mathrm{~b}, 1 \mathrm{k}, 2,3 \mathrm{a}, 3 \mathrm{~b}, 3 \mathrm{c}, 4,5,6,7$ \\
33 & $1 \mathrm{a}, 1 \mathrm{~b}, 1 \mathrm{c}, 1 \mathrm{~d}, 1 \mathrm{k}, 3 \mathrm{~b}, 5,7$ \\
38 & $1 \mathrm{a}, 1 \mathrm{~b}, 1 \mathrm{c}, 1 \mathrm{~d}, 1 \mathrm{k}, 3 \mathrm{a}, 3 \mathrm{~b}, 3 \mathrm{c}, 5,6,7$ \\
\hline
\end{tabular}

${ }^{a}$ Isolates of $P$. sojae are listed as the race designation. $\mathrm{T}$ is used to separate two isolates which would be designated race 30 based on the reaction of the isolate on differentials Rpsla, Rps1b, Rps1c, Rps1d, Rps1k, Rps3a, Rps6, and Rps7.

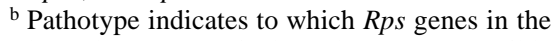
host the $P$. sojae isolates have a susceptible interaction. $P$. sojae races were determined on the following differentials: Williams (universal suscept); Harlon (Rps1a), Harosoy 13XX (Rps1b), Williams 79 (Rps1c); PI103091 (Rpsld); Williams 82 (Rpslk); L761988 (Rps2); L83-570 (Rps3); PRX 146-36 (Rps3b); PRX 145-48 (Rps3c); L85-2352 (Rps4); L85-3059 (Rps5); Harosoy 62XX (Rps6) and Harosoy (Rps7). liter). Colonized areas of the plate were removed and placed in a hypodermic syringe, then mixed to make a slurry by forcing the mycelium and agar through the syringe two times. In all, 8 to 10 seeds of each accession were planted in vermiculite in the greenhouse. After 7 to 10 days, an incision was made in the hypocotyl and approximately 0.2 to $0.4 \mathrm{ml}$ of a mycelium agar slurry was placed in the wound. The plants were covered overnight with plastic to prevent the agar from drying out. Seedlings were evaluated for resistant (hypersensitive) and susceptible reactions 4 to 6 days after inoculations. Inoculations of accessions that were resistance to $P$. sojae races 7,17 , and 25 were repeated five times. Accessions that were inoculated with $P$. sojae races 31, 30-T, 30, 33, and 38 were evaluated a minimum of three times with each race.

Detection of partial resistance. Once a $P$. sojae isolate was identified that had a susceptible interaction with an accession, that isolate was then chosen to evaluate partial resistance. $P$. sojae races $7,17,25$, 30 , and 31 were used to evaluate for partial resistance with the inoculum layer test (17) in 14 separate screenings. Each inoculum layer test was arranged in a randomized complete block design with three replications which included five soybean cultivars with known resistance response. For example, the controls for $P$. sojae race 25 were: Chapman (Rps-3a, resistant), Conrad (high partial resistance), Resnik (moderate partial resistance), Williams (moderately susceptible), and Sloan (susceptible). Standard soybean cvs. Sloan and Conrad were included with each test so that comparisons could be made with all of the accessions evaluated with the different $P$. sojae races. The inoculum consisted of 2 -week-old $P$. sojae cultures grown on dilute lima bean agar (extract from $50 \mathrm{~g}$ of ground lima beans in 1 liter) in glass petri plates. The $P$. sojae-colonized agar was removed intact from the petri plate and placed $5 \mathrm{~cm}$ below the seed (12 soybean seeds per pot) in course vermiculite in 1.2-liter polystyrene containers with bottom drainage. The pots were watered to run-through twice daily. Seedling roots were inoculated with $P$. sojae as they grew through the agar layer. Three weeks after planting, the root mass was removed from the pot, the vermiculite shaken off, and the plants scored on the following scale: $1=$ no root rot; $2=$ up to $10 \%$ root mass rotted; $3=$ up to $25 \%$ of root mass rotted; $4=50 \%$ of root mass rotted; $5=$ all roots rotted, up to $20 \%$ seedlings killed; $6=$ up to $50 \%$ seedlings killed; $7=$ up to $75 \%$ of plants killed; $8=$ up to $90 \%$ seedlings killed; $9=$ all plants killed. In order to compare the results from multiple tests as well as isolates with different levels of aggressiveness, the partial resistance rating of three replications were adjusted for the results from the standard check cultivars, Sloan and Conrad, as follows: the means of the partial resistance rating for the standard cultivars were all adjusted by adding or subtracting 0.5 to 1.5 to equal the scores for Conrad (3.5) and susceptible cv. Sloan (6.0). The scores of the controls were analyzed with the PROC GLM procedure in SAS (SAS Institute, Cary, NC) for the effects of test and test by cultivar interaction. The corrected means for all of the accession data was then pooled and analyzed with PROC GLM using SAS (SAS Institute).

\section{RESULTS}

Sources of Rps genes. Of the 1,015 soybean PIs evaluated for new sources of Rps genes in this study, 159, or approximately $16 \%$, were susceptible to all three races $(7,17$, and 25$)$ of $P$. sojae, indicating that they either had Rps7 or there were no Rps genes present. In contrast, 162, or $16 \%$, were resistant to all three races. Of these 162, 32 were resistant to an additional five races of $P$. sojae (Table 3 ). These additional races (30-T, 30, 31, 33, and 38) have a susceptible interaction with many 2-Rps gene combinations (Table 2). These five isolates of $P$. sojae do not have a susceptible interaction with four 3-Rps gene combinations: Rpslc, Rps3a, Rps4; Rps1c, Rps3b, Rps4; Rps1c, Rps2, Rps3a; and Rps1c, Rps2, Rps3b (Table 3). Therefore, the 130 of the 162 soybean PIs that had a susceptible interaction with these five additional isolates potentially have more than one Rps gene. The possibility also exists that an unidentified Rps gene could have a susceptible interaction with these additional races with a previously unidentified virulence pathotype.

Sources of partial resistance. In all, 49 accessions had a mean root rot rating $\leq 3.0$ and 438 had ratings from 3.1 to 4.0 , indicating very high levels of partial resistance

Table 2. Selected 2 Rps-gene combinations that are susceptible to specific Phytophthora sojae races

\begin{tabular}{ll}
\hline Race & \multicolumn{1}{c}{ Selected susceptible Rps gene combinations } \\
\hline 7 & $1 a, 2 ; 1 a, 3 a ; 1 a, 3 c ; 1 a, 4 ; 1 a, 5 ; 1 a, 6 ; 1 a, 7 ; 2,3 a ; 2,3 c ; 2,4 ; 2,5 ; 2,6 ; 2,7 ; 3 a, 4 ;$ \\
17 & $3 a, 5 ; 3 a, 6 ; 3 a, 7 ; 3 c, 4 ; 3 c, 5 ; 3 c, 6 ; 3 c, 7 ; 4,5 ; 4,6 ; 4,7 ; 5,6 ; 5,7 ; 6,7$ \\
25 & $1 b, 2 ; 1 b, 3 a ; 1 b, 3 c ; 1 b, 4 ; 1 b, 5 ; 1 b, 6 ; 1 b, 7 ; 2,3 b ; 3 b, 4 ; 3 b, 5,3 b, 6,3 b, 7$ \\
31 & $1 c, 7 ; 1 k, 7$ \\
30 & $1 c, 2 ; 1 c, 3 c ; 1 c, 4 ; 1 c, 5 ; 1 c, 6 ; 1 k, 2 ; 1 k, 3 c ; 1 k, 4 ; 1 k, 5 ; 1 k, 6$ \\
$30 \mathrm{~T}$ & $1 k, 3 a$ \\
33 & $1 a, 3 b ; 1 k, 3 b$ \\
38 & $1 c, 3 b$ \\
\hline
\end{tabular}


in the 877 soybean PIs that were inoculated with a race of $P$. sojae that had a susceptible hypocotyl interaction (Fig. 1, Table 4). The levels of partial resistance were equal to or better than the standard cv. Conrad, which has a partial resistance score of 3.5 with most isolates. The standard cultivars which were included in each inoculum layer test were significantly different from each other $(P=0.001)$ and both the greenhouse tests and greenhouse test by cultivar interaction was not significant $(P>0.05)$. The accessions were highly significantly different $(P<0.001)$ for the partial resistance rating. The least significant difference between the accessions was 1.3. Partial resistance scores from the inoculum layer test of 3.0 to 4.0 will have limited yield losses in the field under moderate Phytophthora disease pressure (A. E. Dorrance and S. K. St. Martin, unpublished data).

All but 4 of the 32 soybean PIs that were resistant to all of the races that were used

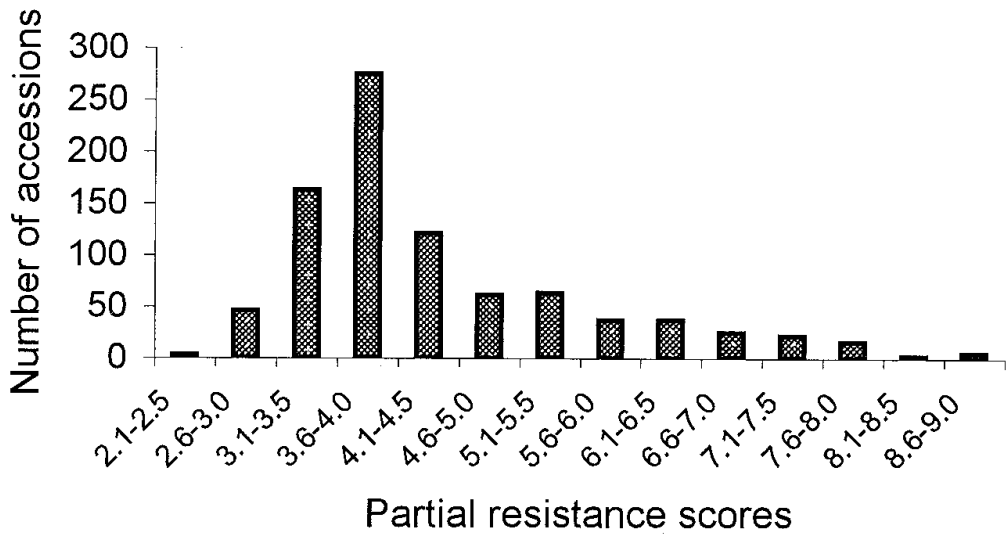

Fig. 1. Greenhouse evaluations for partial resistance of 887 plant introductions (accessions 273.483427.107). Scores are the mean of three replications of the inoculum layer test. In order to compare the results from multiple tests as well as isolates with different levels of aggressiveness, the means of three replications were adjusted for the standard check cultivars which were also evaluated with each experiment: high levels of partial resistance, Conrad (score 3.5); moderate levels of partial resistance, Resnik (score 4.5) and Edison (score 5.5); and susceptible cultivar Sloan (score 6.0).

Table 3. Soybean plant introductions, accessions 273483-427107, with resistance to Phytophthora sojae races following inoculations with each race separately using the hypocotyl inoculation method in the greenhouse ${ }^{\mathrm{a}}$

\begin{tabular}{|c|c|c|c|c|c|c|c|c|c|}
\hline \multirow{2}{*}{$\frac{P . \text { sojae races }}{7,17,25}$} & \multirow{2}{*}{$\frac{\mathbf{M G}^{\mathbf{b}}}{\mathrm{I}}$} & \multirow{2}{*}{$\begin{array}{l}\text { Source }^{\mathbf{c}} \\
\text { Japan }\end{array}$} & \multicolumn{7}{|c|}{ Resistant accessions $^{d}$} \\
\hline & & & 416757 & & & & & & \\
\hline & III & Japan & 417137 & $416918^{\mathrm{NT}}$ & & & & & \\
\hline & III & S. Korea & 399077 & 424540 & & & & & \\
\hline & IV & Japan & 360845 & $378682 \mathrm{~A}$ & 378682B & $378682 \mathrm{C}$ & $416983^{\mathrm{NT}}$ & $417005^{\mathrm{NT}}$ & \\
\hline & IV & S. Korea & 340037 & 340046 & 398276 & 398299 & 398306 & 398495 & 398540 \\
\hline & & & 399006 & 407817 & 407869A & 407959A & 408016B & 408068B & 408074A \\
\hline & & & 408074B & $423827 \mathrm{~A}$ & 423837A & 424171B & 424569B & & \\
\hline $7,17,25,30$ & IV & S. Korea & $273483 \mathrm{C}$ & & & & & & \\
\hline $7,17,25,31$ & IV & S. Korea & 408004-1 & $408020 \mathrm{~A}$ & & & & & \\
\hline \multirow[t]{3}{*}{$7,17,25,30 \mathrm{~T}$} & III & Japan & 393537 & 423885 & & & & & \\
\hline & IV & Japan & 393540 & 417412 & 423910 & & & & \\
\hline & IV & S. Korea & 398298 & 398680 & 399022 & 407778A & 408319A & $424348 C$ & 424549B \\
\hline $7,17,25,30 \mathrm{~T}, 33$ & IV & S. Korea & 407781B & & & & & & \\
\hline $7,17,25,30,31$ & IV & S. Korea & 408108 & & & & & & \\
\hline $7,17,25,30 \mathrm{~T}, 31$ & IV & S. Korea & 398996 & $407781 \mathrm{~A}$ & 408169A & $424406 \mathrm{~A}$ & $424249 \mathrm{C}$ & 424409 & 424414 \\
\hline \multirow[t]{8}{*}{$7,17,25,30,30 \mathrm{~T}, 31$} & III & S. Korea & 399008 & 399080 & 424358 & & & & \\
\hline & IV & S. Korea & 398249 & 398371 & 398565 & 398674 & 398764 & 398773 & 398774 \\
\hline & & & 398775 & 398790 & 398791 & 398880 & 398940 & 398944 & 398946 \\
\hline & & & 399015 & 407772B & 407812 & 407847 & 407934 & 407960B & 408017 \\
\hline & & & $408020 \mathrm{C}$ & 408062 & 408111 & 408124A & $408124 \mathrm{C}$ & $408125 \mathrm{C}$ & 408132 \\
\hline & & & 408196B & 408224B & 408260B & 408288 & 423741 & 423850 & 424135 \\
\hline & & & 424238 & $424342 B$ & 424430 & 424450 & 424477 & 424479 & 424509 \\
\hline & & & 424525 & 424529 & 424549A & $424555 B$ & 424559 & 424615 & \\
\hline $7,17,25,30,30 \mathrm{~T}, 33$ & IV & S. Korea & 398223 & 424355 & & & & & \\
\hline $7,17,25,30,31,33$ & IV & Japan & 274421 & & & & & & \\
\hline $7,17,25,30,31,33,38$ & IV & S. Korea & 340035 & & & & & & \\
\hline \multirow[t]{2}{*}{$7,17,25,30,30 \mathrm{~T}, 33,38$} & III & Japan & 393538 & & & & & & \\
\hline & IV & S. Korea & 423858 & & & & & & \\
\hline $7,17,25,30 \mathrm{~T}, 31,33,38$ & II & Japan & 423871 & & & & & & \\
\hline \multirow[t]{4}{*}{$7,17,25,30,30 \mathrm{~T}, 31,33$} & III & S. Korea & 398275 & 424159A & & & & & \\
\hline & IV & S. Korea & 398664 & 398959 & 399004 & 399017 & 407806A & 407823 & 407900 \\
\hline & & & 408210 & 408287 & 408319B & 424237A & 424320 & 424413 & 424499A \\
\hline & & & $424499 \mathrm{C}$ & 424531 & & & & & \\
\hline \multirow{7}{*}{$7,17,25,30,30 \mathrm{~T}, 31,33,38$} & III & Japan & 274456 & 417229 & & & & & \\
\hline & III & S. Korea & 398295 & 398643 & 398693 & 398694 & 398697 & 407974B & 424247A \\
\hline & IV & Japan & 416840 & & & & & & \\
\hline & IV & Russia & 404159 & & & & & & \\
\hline & IV & S. Korea & 273483D & 398440 & 398666 & 399036 & 399073 & 399079 & $407861 \mathrm{C}$ \\
\hline & & & 407985 & 408015 & 408029 & 408097 & 408137A & 408211B & $408225 \mathrm{~A}$ \\
\hline & & & $408319 \mathrm{C}$ & $424169 A$ & 424234B & 424247B & 424354 & 424487B & 424533 \\
\hline
\end{tabular}

\footnotetext{
${ }^{a}$ Each accession was evaluated with each race separately. Eight seedlings were inoculated with a mycelium slurry from a 7-day-old culture of $P$. sojae in the hypocotyl with a syringe. After 5 days, reactions were recorded as resistant or susceptible. Inoculations were repeated three times for each race.

${ }^{\mathrm{b}} \mathrm{MG}=$ maturity group as designated in Nelson et al. (12). Note: both MG IV and late IVs as designated (12) are combined in this table.

${ }^{c}$ Seed source $=$ source of the actual seeds that were submitted to the USDA Soybean Germplasm collection at Urbana, IL.

${ }^{\mathrm{d}} \mathrm{NT}=$ not tested for any additional races due to lack of seed.
} 
Table 4. Soybean plant introductions, accessions 273483-427107, with high levels of partial resistance (scores 2.5 to 3.9) to Phytophthora sojae as determined by the inoculum layer test in greenhouse evaluations ${ }^{\mathrm{a}}$

\begin{tabular}{|c|c|c|c|c|c|c|c|}
\hline \multirow{2}{*}{$\frac{\mathbf{M G}^{\mathbf{b}}}{000}$} & \multicolumn{7}{|c|}{ Soybean plant introduction accession number } \\
\hline & 379563 & & & & & & \\
\hline 00 & 361078 & 417564 & 423707 & $417512 \mathrm{~A}$ & 417512B & & \\
\hline 0 & 407707 & 416845 & 417095 & 417187 & 423864 & 423954 & \\
\hline \multirow[t]{2}{*}{ I } & 407705 & 416878 & 416915 & 417012 & 417210 & 417244 & 417453 \\
\hline & 416805 & 416910 & 416946 & 417143 & 417227 & 417296 & \\
\hline \multirow[t]{3}{*}{ II } & 291327 & 416875 & 417142 & 417173 & 417274 & 423933 & $427105 B$ \\
\hline & $404196 \mathrm{~A}$ & 417020 & 417154 & 417246 & 417315 & 423941 & 427106 \\
\hline & 407661 & 417062 & 417160 & 417255 & 417459 & 423951 & \\
\hline \multirow{12}{*}{ III } & 339995 & 398755 & 408048A & 416916 & 417303 & 424366 & \\
\hline & 340017 & 398806 & 408048B & 416918 & 417354 & $424444 \mathrm{~A}$ & \\
\hline & 342438 & 398814 & $408052 \mathrm{~A}$ & 416988 & $423747 \mathrm{~A}$ & 424568 & \\
\hline & 360841 & 398841 & $408138 \mathrm{C}$ & 416991 & 423814A & $424569 A$ & \\
\hline & 393537 & 399077 & $408255 \mathrm{~A}$ & 416993 & 423818 & & \\
\hline & 398227 & 404169B & $408312 \mathrm{~A}$ & 417015 & 423885 & & \\
\hline & 398230 & 404188B & 416753 & 417032 & 423896 & & \\
\hline & 398297 & 407850 & 416823 & 417152 & 423946 & & \\
\hline & 398395 & 407907A & 416856 & 417161 & 423948B & & \\
\hline & 398494 & 407922 & 416868B & 417177 & 424134 & & \\
\hline & 398710 & 407926B & 416889 & 417178 & 424143 & & \\
\hline & 398737 & 407933 & 416896 & 417192 & $424155 \mathrm{~A}$ & & \\
\hline \multirow[t]{27}{*}{ IV } & 274212 & 398857 & 407827 & 408114 & 417001 & $424234 \mathrm{~A}$ & \\
\hline & $339864 \mathrm{~A}$ & 398887 & $407833 \mathrm{~A}$ & $408135 B$ & 417003 & 424249D & \\
\hline & 339868D & 398970 & $407845 \mathrm{~A}$ & $408140 \mathrm{~A}$ & 417004 & 424264 & \\
\hline & 398191 & 399001 & 407848 & 408140B & 417092 & $424285 \mathrm{~A}$ & \\
\hline & 398198 & 399016 & 407862 & 408169D & 417176 & $424285 \mathrm{C}$ & \\
\hline & 398242 & 399027 & 407877A & 408201B & 417200 & 424305 & \\
\hline & 398243 & 399051 & 407877B & $408211 \mathrm{~A}$ & 417202 & $424349 B$ & \\
\hline & 398244 & 399119 & $407892 \mathrm{~A}$ & $408224 \mathrm{~A}$ & 417245 & 424349C & \\
\hline & 398272 & 404183 & 407908 & 408236 & 417279 & 424389 & \\
\hline & 398276 & 404185 & 407914A & 408258 & 417283 & 424397 & \\
\hline & 398298 & 404197 & 407959A & $408265 B$ & 417298 & $424405 \mathrm{C}$ & \\
\hline & 398306 & $407658 \mathrm{~A}$ & $407960 \mathrm{~A}$ & $408269 \mathrm{~A}$ & 417336 & 424429 & \\
\hline & 398317 & $407658 \mathrm{C}$ & 407981A & $408269 B$ & 417368 & 424444B & \\
\hline & 398321 & 407727 & 408016B & $408272 B$ & 417424 & $424504 B$ & \\
\hline & 398359 & 407770 & 408819B & 408275 & 417479 & 424511 & \\
\hline & 398386 & $407772 \mathrm{~A}$ & 408050B & 408280 & 417488 & 424512 & \\
\hline & 398495 & 407773B & $408055 \mathrm{~A}$ & $408281 \mathrm{~A}$ & 420338 & 424528 & \\
\hline & 398640 & $407778 \mathrm{~A}$ & 408057 & $408295 \mathrm{~A}$ & 423893 & $424535 \mathrm{~A}$ & \\
\hline & 398656 & 407786A & $408068 \mathrm{~A}$ & 408318A & 423977 & $424546 \mathrm{~A}$ & \\
\hline & 398741 & 407788B & 408076A & $416769 C$ & 423979 & $424549 \mathrm{~B}$ & \\
\hline & 398765 & 407795B & 408079A & 416914 & 424152 & $424569 \mathrm{~B}$ & \\
\hline & 398772 & $407805 \mathrm{C}$ & 408090 & 416963 & $424154 \mathrm{~A}$ & 424604 & \\
\hline & 398804 & $407805 \mathrm{D}$ & $408092 \mathrm{~A}$ & 416965 & 424155B & 424608A & \\
\hline & 398805 & 407806B & $408095 \mathrm{~A}$ & 416968 & 424159C & & \\
\hline & 398815 & 407817 & 408095B & 416984 & 424160 & & \\
\hline & 398820 & 407818A & 408105A & 416987 & $424219 \mathrm{~A}$ & & \\
\hline & 398847 & 407821A & 408105B & 416997 & & & \\
\hline \multirow[t]{21}{*}{ L-IV } & 274205 & 399006 & $407913 \mathrm{~A}$ & $408212 B$ & 423842 & 424352 & \\
\hline & 339981 & 399018 & 407913B & $408222 \mathrm{C}$ & 423877 & 424400 & \\
\hline & 340034 & 399019 & 407914D & 408227 & 423902 & 424412 & \\
\hline & 340037 & 399020 & 407917 & $408272 \mathrm{C}$ & 423975 & 424426 & \\
\hline & 342004 & 399022 & 407918B & 408289 & 423983 & 424458 & \\
\hline & 361103 & 399023 & 407924 & 408300 & $424164 \mathrm{~A}$ & 424495 & \\
\hline & 379560 & 399028 & 407927B & $408307 \mathrm{C}$ & $424168 \mathrm{~A}$ & 424499D & \\
\hline & 398282 & 406708 & 407928 & $408335 B$ & 424168B & $424521 \mathrm{~A}$ & \\
\hline & 398299 & 407776 & 407959B & 416801 & 424169B & 424527 & \\
\hline & 398303 & $407778 \mathrm{C}$ & $407975 \mathrm{~A}$ & 416839 & $424171 \mathrm{~A}$ & 424536 & \\
\hline & 398355 & 407818B & 408816A & 416958 & $424214 \mathrm{~A}$ & 424544 & \\
\hline & 398375 & 407820 & 408019C & 416959 & $424214 C$ & 424566 & \\
\hline & 398389 & 407863 & 408068B & 417412 & $424221 B$ & 424572 & \\
\hline & 398464 & 407867B & 408074B & 423789 & $424255 \mathrm{C}$ & 424582 & \\
\hline & 398631 & $407869 \mathrm{~A}$ & 408076B & 423791 & 424257B & 424583 & \\
\hline & 398717 & 407869B & 408124D & 423792 & 424276 & 424592 & \\
\hline & 398843 & $407872 \mathrm{C}$ & $408166 \mathrm{~A}$ & 423811 & $424278 \mathrm{~B}$ & 424607 & \\
\hline & 398919 & 407873 & 408169B & $423827 \mathrm{~A}$ & 424293 & $424608 B$ & \\
\hline & 398985 & $407892 \mathrm{C}$ & 408173 & $423833 \mathrm{~A}$ & 424294B & 424612 & \\
\hline & 398987 & 407895 & 408186B & 423836 & 424344 & & \\
\hline & 398988 & 407906 & 408197A & $423837 \mathrm{~A}$ & $424348 \mathrm{C}$ & & \\
\hline
\end{tabular}

a Accessions were rated on the following scale: $1=$ no root rot; $2=$ up to $10 \%$ of root mass rotted; $3=$ up to $25 \%$ of root mass rotted; $4=50 \%$ of root mass rotted; $5=$ all roots rotted, up to $20 \%$ of seedlings killed; $6=$ up to $50 \%$ of seedlings killed; $7=$ up to $75 \%$ of plants killed; $8=$ up to $90 \%$ of seedlings killed; $9=$ all plants killed.

${ }^{\mathrm{b}} \mathrm{MG}=$ maturity group. 
in this study were collected in South Korea. In addition, $67.6 \%$ of the lines with high levels of partial resistance were also collected from South Korea. Previous efforts to evaluate germ plasm has focused on soybean production regions in People's Republic of China.

\section{DISCUSSION}

In order to detect new sources of resistance to $P$. sojae with potentially novel $R p s$ genes, we used a strategy of inoculating soybean germ plasm with isolates with specific pathotypes that would provide a susceptible reaction with all of the known $R p s$ genes, as well as 2-Rps and many 3Rps gene combinations. This follows Flor's (6) hypothesis that resistance genes may be identified based on the susceptible or resistance response following inoculations with races of a pathogen with known virulence pathotypes. Lohnes et al. (11) screened a collection of PIs with only four races of $P$. sojae. Although these isolates, $P$. sojae races $1,7,17$, and 25 , have a susceptible interaction with all of the Rps genes that have been identified to date, there are many 2-Rps gene combinations (Table 2) that would have a resistant interaction when inoculated with these isolates. Athow et al. (3) reported two Rps genes in each of five accessions in their study, three of which were also evaluated in this study. Rennie et al. (14) identified two Rps genes in Japanese cultivars. Soybean breeders could potentially begin to incorporate these "new sources" of resistance into U.S. germ plasm when, in fact, the resistance is a 2-Rps gene combination for which races of $P$. sojae already exist that have susceptible interactions. Ultimately, once a source of resistance is identified, inheritance studies will be necessary to identify if it is an additional allele at a known locus or a new locus altogether, as well as the number of genes involved, to verify if the source contains a truly "novel gene".

Sources of resistance to host-specific plant pathogens are often found in regions of the greatest differentiation within the host species $(10,24)$. In theory, both host and pathogen have putatively coevolved in these regions over long periods of time and this protracted association leads to diversity. Previous efforts to identify new sources of resistance in soybeans have focused primarily on accessions collected in the People's Republic of China $(9,11)$. A high percentage of the soybean accessions in eastern China, specifically in the provinces of Anhui, Hubei, Jiangsu, and Sichuan, have been identified as having resistance to a number of $P$. sojae races $(9,11)$. It was proposed that the diversity of resistance was due to the favorable environmental conditions for $P$. sojae that exist in these regions due to the significant amounts of rainfall: $2,000 \mathrm{~mm}$ in Anhui and Jiangsu $(5,9,11)$.
The majority of the accessions ( 28 out of 32) that were resistant to all of the races of $P$. sojae tested in this study were collected from South Korea, including Chongju, Chonju, Ch'unch'on, Kwangju, Masan, Seoul, Taegu, and Taejon (12). In addition, $68 \%$ of accessions that were evaluated had very high levels of partial resistance, a trait that is thought to be controlled by several genes. Environmental conditions which would favor $P$. sojae also exist in this region because average rainfall is nearly $1,250 \mathrm{~mm}$ per year in South Korea and is concentrated from April through September (23). In Athow and Laviolette's (12) previous screening of this collection (PI273483 to PI 427107), approximately $29 \%$ of the accessions from South Korea were resistant to more than one race of $P$. sojae. This is comparable with earlier results reported for accessions from eastern China (11). These results suggest that South Korea may be another region to explore for additional sources of Rps genes as well as partial resistance to $P$. sojae.

$P$. sojae was only recently identified as a soybean pathogen in China: during 1989 in the Heilongjiang and Jilin provinces and Beijing City in Northern China (27) and during 1996 in the Chungnam province of Korea (8). Although resistance to $P$. sojae has been identified in these regions, a significant proportion of the accessions are also susceptible to $P$. sojae race 1 (vir 7) (11). The soybean accessions screened in this and other studies $(9,11)$ have been land races, originating from farmers' garden plots. It is conceivable that garden cultivation is not favorable for the development of Phytophthora root rot, potentially due to good disease management practices (improved drainage, rotations, high organic matter). If $P$. sojae is present in these soils, it may be present at very low levels, or antagonists may also be present in the soil. It is possible that the Rps genes identified in these accessions were indirectly selected because of linkage to a favorable trait, and have been maintained in the germ plasm for several millennia. Examining the wild soybean for resistance and the genetic diversity of $P$. sojae within these regions will ultimately lead to a greater understanding of where these two species coevolved. Determining the region where these two species coevolved should help to focus screening efforts on the region where potentially more sources of novel Rps genes and genes which impart partial resistance may exist.

Based on the susceptible response to inoculations with of $P$. sojae isolates with specific virulence pathotypes, many accessions tested must have more than one Rps gene. The presence of multiple Rps genes within germ plasm poses a risk of falsely attributing resistance to a novel source when, in fact, a combination of known Rps genes are present. Therefore, the selection of which isolates to screen for new sources of resistance becomes critical. Many races of $P$. sojae have been identified in the past 10 years $(1,2,7,15,18,28)$. Fortunately, we now have the ability to identify races with specific virulence pathotypes to screen for single Rps genes and Rps gene combinations. All of the $P$. sojae isolates that we chose for this study were complex, in that they had a susceptible interaction with five or more of the single Rps gene differentials. Using this screening technique should expedite evaluation and confirmation of novel Rps genes. Ultimately, if novel sources of Rps genes do become limited, then the South Korean germ plasm will serve as an excellent source of high levels of partial resistance for management of $P$. sojae.

\section{ACKNOWLEDGMENTS}

We thank S. A. McClure for technical assistance and L. Madden and P. Lipps for providing comments and suggestions regarding this manuscript.

\section{LITERATURE CITED}

1. Abney, T. S., Melgar, J. C., Richards, T. L., Scott, D. H., Grogan, J., and Young, J. 1997 New races of Phytophthora sojae with Rps1-d virulence. Plant Dis. 81:653-655.

2. Anderson, T. R., and Buzzell, R. I. 1992. Diversity and frequency of races of Phytophthora megasperma f. sp. glycinea in soybean fields in Essex County, Ontario, 19801989. Plant Dis. 76:587-589.

3. Athow, K. L., Laviolette, F. A., Layton Hahn, A. C., and Ploper, L. D. 1986. Genes for resistance to Phytophthora megasperma f. sp. glycinea in PI 273483D, PI 64747, PI 274212 , PI 82312N, and PI 340046. Soybean Genet. Newsl. 13:119-131.

4. Buzzell, R. I., and Anderson, T. R. 1982. Plant loss response of soybean cultivars to Phytophthora megasperma f. sp. glycinea under field conditions. Plant Dis. 66:1146-1148.

5. Committee for the World Atlas of Agriculture 1973. Pages 78-89 in: The World Atlas of Agriculture, V2. Istituto Geografico De Agostini, Novara.

6. Flor, H. H. 1955. Host parasite interaction in flax rust-its genetics and other implications. Phytopathology 45:680-685.

7. Förster, H., Tyler, B. M., and Coffey, M. D. 1994. Phytophthora sojae races have arisen by clonal evolution and by rare outcrosses. Mol. Plant-Microbe Interact. 7:780-791.

8. Jee, H., Kim, W., and Cho, W. 1998. Occurrence of Phytophthora root rot on soybean (Glycine max) and identification of the causal fungus. RDA. J. Crop Prot. 40:16-22.

9. Kyle, D. E., Nickell, C. D., Nelson, R. L., and Pedersen, W. L. 1998. Response of soybean accessions from provinces in southern China to Phytophthora sojae. Plant Dis. 82:555-559.

10. Leppik, E. E. 1970. Gene center of plants as sources of disease resistance. Annu. Rev. Phytopathol. 8:323-344.

11. Lohnes, D. G., Nickell, C. D., and Schmitthenner, A. F. 1996. Origin of soybean alleles for Phytophthora resistance in China. Crop Sci. 36:1689-1692.

12. Nelson, R. L., Amdor, P. J., Orf, J. H., Lambert, J. W., Cavins, J. F., Kleiman, R., Laviolette, F. A., and Athow, K. L. 1987. Evaluation of the USDA-ARS Soybean Germplasm Collection: Maturity Groups 000 to IV (PI 273.483 to PI 427.107) USDA Tech. Bull. 1718, Washington, DC.

13. Pratt, P. W., and Wrather, J. A. 1998. Soybean 
disease loss estimates for the Southern United States, 1994 to 1996. Plant Dis. 82:114-116.

14. Rennie, B. D., Buzzell, R. I., Anderson, T. R., and Beversdorf, W. D. 1992. Evaluation of four Japanese soybean cultivars for Rps alleles conferring resistance to Phytophthora megasperma f. sp. glycinea. Can. J. Plant Sci. 72:217-220.

15. Ryley, M. J., Obst, N. R., Irwin, J. A. G., and Drenth, A. 1998. Changes in the racial composition of Phytophthora sojae in Australia between 1979 and 1996. Plant Dis. 82:10481054.

16. Schmitthenner, A. F. 1985. Problems and progress in control of Phytophthora root rot of soybean. Plant Dis. 69:362-368.

17. Schmitthenner, A. F., and Bhat, R. G. 1994 Useful Methods for Studying Phytophthora in the Laboratory. Ohio Agric. Res. Dev. Cent. Spec. Circ. 143.

18. Schmitthenner, A. F., Hobe, M., and Bhat, R. G. 1994. Phytophthora sojae races in Ohio over a 10-year interval. Plant Dis. 78:269276.

19. St. Martin, S. K., Scott, D. R., Schmitthenner, A. F., and McBlain, B. A. 1994. Relationship between tolerance to Phytophthora rot and soybean yield. Plant Breed. 113:331-334.

20. Tooley, P. W., and Grau, C. R. 1982. Identification and quantitative characterization of rate-reducing resistance to Phytophthora megasperma f. sp. glycinea in soybean seedlings. Phytopathology 72:727-733.

21. Tooley, P. W., and Grau, C. R. 1982. Races of Phytophthora megasperma f. sp. glycinea in Wisconsin. Plant Dis. 66:472-475.

22. Tooley, P. W., and Grau, C. R. 1984. The relationship between rate-reducing resistance to Phytophthora megasperma f. sp. glycinea and yield of soybean. Phytopathology 74:1209-1216.

23. Turner, B. (ed.). 2000. Pages $976-977$ in: The Statesman's Yearbook. St. Martin's Press, New York.
24. Vavilov, N. I. 1949-1950. The origin, variation, immunity and breeding of cultivated plants. Chron. Bot. 13:1-364.

25. Walker, A. K., and Schmitthenner, A. F. 1984 Comparison of field and greenhouse evaluations for tolerance to Phytophthora rot in soybean. Crop Sci. 24:487-489.

26. Wrather, J. A., Anderson, T. R., Arsyad, D. M., Gai, J., Ploper, L. D., Porta-Puglia, A. Ram, H. H., and Yorinori, J. T. 1997. Soybean disease loss estimates for the top 10 soybean producing countries in 1994. Plant Dis. 81:107-110.

27. Yanchun, S., and Chongyao, S. 1993. The discovery and biological characteristics studies of Phytophthora megasperma f. sp. glycinea on soybean in China. Acta Phytopathol. Sin. 23:341-347.

28. Yang, X. B., Ruff, R. L., Meng, X. Q., and Workneh, F. 1996. Races of Phytophthora sojae in Iowa soybean fields. Plant Dis. 80:1418-1420. 